\title{
ANALISIS KESESUAIAN LAHAN UNTUK LOKASI PERMUKIMAN DI KABUPATEN BELU NUSA TENGGARA TIMUR
}

\author{
Ogi Dani Sakarov ${ }^{1}$ \\ Kletus Fahik ${ }^{2}$ \\ Program Studi Perencanaan Wilayah dan Kota Institut Teknologi Nasional Yogyakarta ${ }^{1,2}$ \\ Penulis Korespondensi e-mail: ogidanisakarov@gmail.com
}

\begin{abstract}
Article 28 of the 1945 Constitution explains that housing is a basic right for every citizen. It can be understood that the constitution requires the government to fulfill the needs of the home for the people of Indonesia. Until now, the government has launched various housing and settlement procurement and development programs both in the national, provincial and regional scope. At the regional level, where the government has a role as a technical implementer, it should carry out various analyzes to determine the suitable location for the regional settlement area. Therefore, this research was carried out to assist the government in determining the appropriate location for residential areas in Belu District, East Nusa Tenggara. The analytical method that used in this study is quantitative analysis with a spatial analysis approach that uses land suitability analysis in Arch GIS 10.2 software, where the analysis is done by scoring and weighting the land suitability determinant variables namely physical aspects, infrastructure, accessibility, disaster and socio-cultural. The results of this analysis are that land in the Belu Regency area that is feasible or potential as a location for settlements consists of three suitability classes namely very suitable class (S1) covering 3,566.38 hectares, corresponding class (S2) covering 5,933.49 hectares and classes are quite appropriate (S3) covering an area of 25,3166.59 hectares.
\end{abstract}

Keywords: housing, settlements, land suitability analysis, social culture

\begin{abstract}
ABSTRAK
Undang-Undang Dasar 1945 pasal 28 menjelaskan bahwa rumah merupakan hak dasar bagi setiap warga negara. Hal tersebut dapat dipahami bahwa undang-undang dasar mewajibkan pemerintah untuk memenuhi kebutuhan rumah bagi masyarakat Indonesia. Hingga saat ini pemerintah telah mencanangkan berbagai program pengadaan dan pengembangan perumahan dan permukiman baik dalam lingkup nasional, provinsi maupun daerah. Pada tingkat daerah, dimana pemerintah memegang peran sebagai pelaksana teknis, hendaknya melakukan berbagai analisis untuk menentukan lokasi yang cocok untuk kawasan permukiman daerah. Oleh karena itu, penelitian ini dilaksanakan untuk membantu pemerintah dalam menentukan lokasi yang sesuai untuk kawasan permukiman di Kabupaten Belu, Nusa Tenggara Timur. Metode analisis yang digunakan dalam penelitian ini adalah analisis kuantitatif dengan pendekatan analisis spasial yang menggunakan teknik analisis kesesuaian lahan pada software Arch GIS 10.2, dimana analisis dilakukan dengan pengskoringan dan pembobotan terhadap variabel penentu kesesuaian lahan yakni aspek fisik, prasarana, aksesibilitas, kebencanaan dan sosial budaya. Hasil analisis ini adalah lahan pada wilayah Kabupaten Belu yang layak atau potensial sebagai lokasi untuk permukiman terdiri atas tiga kelas kesesuaian yakni kelas sangat sesuai (S1) seluas 3.566,38 Hektar, kelas sesuai (S2) seluas 5.933,49 Hektar dan kelas cukup sesuai (S3) seluas 25.3166,59 Hektar.
\end{abstract}

Kata kunci: perumahan, permukiman, analisis kesesuaian lahan, social budaya 


\section{PENDAHULUAN}

Menurut UU RI No 1 tahun 2011 tentang perumahan dan kawasan permukiman, permukiman merupakan bagian dari lingkungan hunian yang terdiri dari lebih dari satu satuan perumahan yang memiliki prasarana, sarana, utilitas umum, serta mempunyai penunjang kegiatan fungsi di kawasan perkotaan maupun perdesaan. Apabila dilihat berdasarkan kelengkapan dan tingkat kenyamanan dan kemudahan, infrasturktur jalan sebagai aksesibilitas merupakan salah satu variabel yang menjadi perhatian (Sakarov, 2018). Pada pengembangan permukiman permasalahan yang sering dihadapi yakni adanya faktor-faktor pembatas fisik berupa topografi, geologi, dan hidrologi. Permasalahan relief yang dihadapi di Kabupaten Belu dimana hampir secara keseluruhan wilayah Kabupaten Belu memiliki relief yang memiliki kemiringan lebih dari 30\%. Dengan kondisi yang demikian, permasalahan yang dihadapi bila terjadi hujan dengan intensitas yang tinggi berupa erosi permukaan. Pada waktu kemarau permasalahan yang dihadapi berupa kekurangan air. Selain itu kondisi sarana dan prasarana penunjang di kabupaten Belu belum secara menyeluruh menyentuh wilayah yang ada di kabupaten Belu.

Adapun pertanyaan penelitian adalah bagaimana tingkat kesesuaian lahan untuk permukiman berdasarkan aspek fisik dasar, aspek aksesibilitas, aspek prasarana lingkungan, aspek kebencanaan dan aspek sosial budaya di Kabupaten Belu. Hal ini menarik untuk diteliti karena fenomena tata guna lahan di Kabupaten Belu berjalan sangat dinamis, dimana penulis mencoba untuk memasukan aspek sosial budaya dalam analisis tata guna lahan permukiman.

Ruang Lingkup Wilayah penelitian ini adalah seluruh wilayah administrasi Kabupaten Belu. Kabupaten Belu merupakan salah satu wilayah yang berbatasan langsung dengan Negara Timor Leste. Kabupaten Belu terdiri atas 12 Kecamatan dan 81 desa yang terbagi menjadi 5 desa pesisir dan 76 desa non-pesisir dengan luas wilayah adalah 112.325,68 Ha. Kabupaten Belu secara administrasi berbatasan dengan Selat Ombai dibagian Utara, Kabupaten Malaka di sebelah Selatan, sebelah Timur berbatasan dengan Negara Timor Leste dan sebelah Barat berbatasan dengan Kabupaten Timor Tengah Utara dan Timor Tengah Selatan. Berikut Gambar 1 tentang peta lokasi penelitian: 


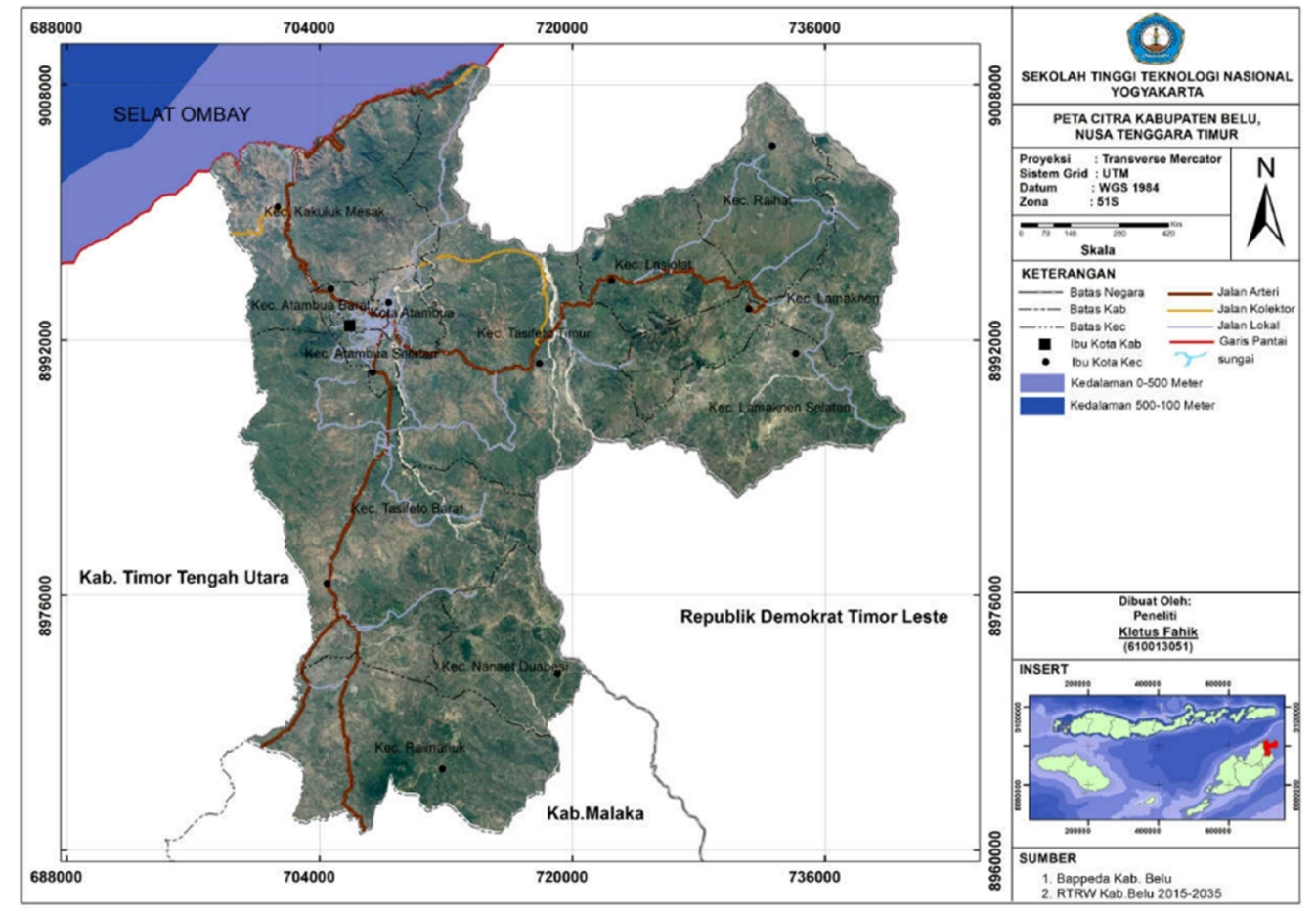

Gambar 1. Lokasi Penelitian

Sumber: Analisis, 2019

Ruang Lingkup Substansi penelitian yaitu sebagaimana tujuan yang ingin dicapai dari penelitian ini, maka ruang lingkup yang akan dibahas antara lain (1) Aspek fisik dasar, aksesibilitas, prasarana lingkungan, kebencanaan serta sosial budaya dan (2) Kesesuaian lahan untuk lokasi permukiman.

\section{METODOLOGI}

\section{A. Pendekatan penelitian}

Penelitian ini menggunakan pendekatan deduktif kualitatif. Untuk Teknik analisis, penulis menggunakan analisis spasial-kuantitatif dimana data-data yang digunakan akan dilakukan scoring sesuai variabel atau parameter yang telah ditentukan, yang selanjutnya akan diolah agar dapat mencapai tujuan yang diinginkan dalam penelitian ini.

\section{B. Rancangan Penelitian}

Data yang dibutuhkan pada penelitian ini antara lain data kuantitatif dan data kualitatif. Untuk data kuantitatif, diambil dari data sekunder yang bersumber dari instansi pemerintah, sedangkan data kualitatif diambil dari wawancara dan observasi masyarakat.

Tabel 1. Rincian Kebutuhan Data

\begin{tabular}{|c|c|}
\hline Variabel & Sumber Data \\
\hline $\begin{array}{l}\text { 1. Data tata guna lahan dan } \\
\text { tematik lain yang digunakan }\end{array}$ & Instansi \\
\hline
\end{tabular}


Jurnal Planologi Vol. 16, No. 1, April 2019

\begin{tabular}{|c|c|}
\hline Variabel & Sumber Data \\
\hline & daerah \\
\hline $\begin{array}{l}\text { 2. Kondisi sosial masyarakat } \\
\text { berdasarkan suku-suku }\end{array}$ & $\begin{array}{l}\text { Wawancara dan observasi } \\
\text { lapangan }\end{array}$ \\
\hline
\end{tabular}

Sumber: Analisis Peneliti, 2019

Penelitian ini menggunakan data primer dan sekunder, dimana teknik untuk mendapatkan data dibedakan menurut pembagian tersebut. Penggumpulan data sekunder ini dilakukan dengan mencari data yang dibutuhkan pada instansi atau lembaga terkait seperti BAPPEDA Kabupaten Belu, BPS, Dinas PU Kabupaten Belu dan Dinas PU provinsi. Kebutuhan data ini diperlukan untuk memperoleh parameter - parameter utama yang digunakan dalam penelitian ini yakni data fisik dasar wilayah penelitian, aksesibilitas, dan sarana prasarana lingkungan dalam bentuk peta JPG maupun shapefile berupa, karakteristik tanah, kemiringan lereng, banjir, curah hujan, jaringan jalan, prasarana, serta data-data terkait. Sedangkan terhadap data sosial budaya, digunakan teknik wawancara dengan menggunakan metode purposive sampling dimana narasumbernya telah ditentukan terlebih dahulu dan menggunkan metode cluster sampling dikarenakan populasi dan sumber datanya sangat luas.

Analisis yang dipakai untuk dijadikan alat untuk mengetahui kesesuaian lahan untuk lokasi permukiman adalah dengan menerapkan konsep GIS dengan menggunakan analisis tolls. Berikut skema analisis penelitiannya: 


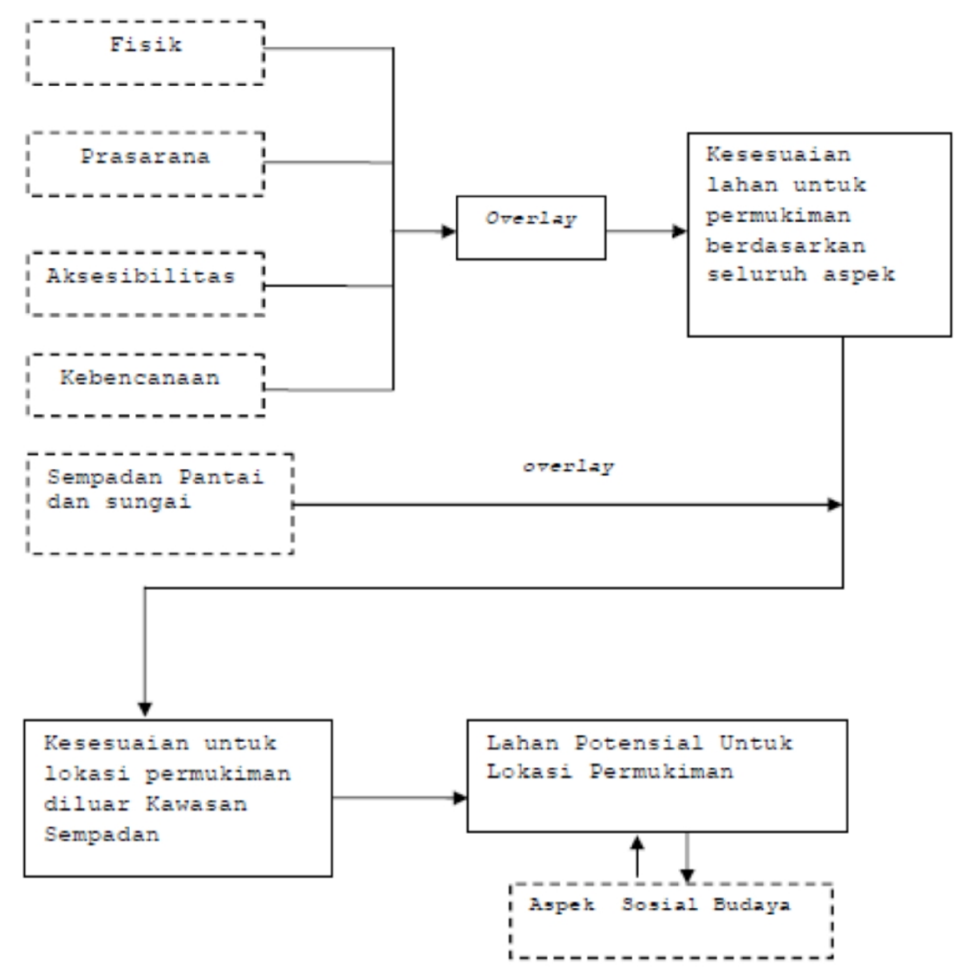

Gambar 2. Skema Analisis Penelitian Sumber: Analisis, 2019

\section{HASIL DAN PEMBAHASAN}

\section{A. Analisis peruntukan Lahan Kawasan}

Analisis ini dilakukan dengan menumpangsusukan parameter kemiringan lereng, jenis tanah dan curah hujan berdasarkan tinjauan SK Mentan No No.837/KPTS/UM/11/1980 dan No.683/KPTS/UM/8/1981. Peruntukan lahan di Kabupaten Belu terbagi menjadi 2 kawasan yakni kawasan penyangga dengan luas 16.717,43 Ha dan kawasan budidaya dengan luas 95.608,25 Ha. Kawasan budidaya dibagi lagi menjadi dua yakni kawasan budidaya untuk permukiman dengan luas 33.036,37 Ha dan kawasan budidaya untuk tanaman tahunan dengan luas 62,571,88 Ha. 


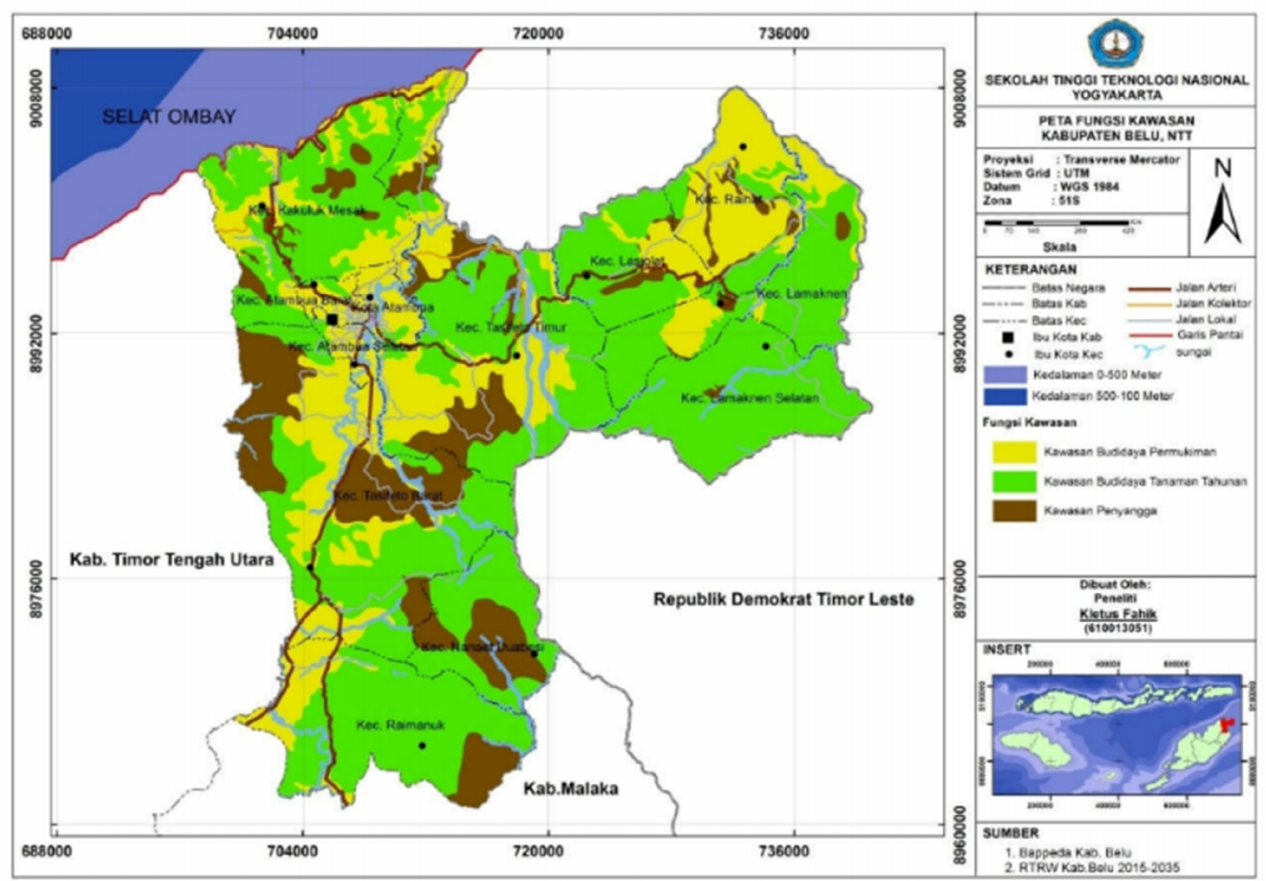

Gambar 3. Peta Analisis Peruntukan Lahan Sumber: Analisis, 2018

\section{B. Analisis Kesesuaian Aspek Fisik}

Analisis aspek fisik lahan dilakukan untuk mendapatkan kesesuaian lahan berdasarkan aspek fisik dengan melibatkan beberapa parameter yakni kemiringan lereng, jenis tanah, kedalaman tanah, dan curah hujan (Budiharjo, 1999). Analisis ini dilakukan dengan menggunakan analisis tools berupa overlay keempat parameter tersebut. Tingkat kesesuaian aspek fisik ini tersebar diseluruh wilayah Kabupaten Belu dengan luas kelas kurang sesuai (N1) dengan luas sebesar 63.625,80 atau sekitar 57\% dari total keseluruhannya. Selanjutnya diikuti oleh kelas N2 dengan luas 20.936,13. Sedangkan kategori sesuai didominasi oleh kelas cukup sesuai (S3) dengan luas 18.368,41 Ha. Keadaan ini disebabkan oleh kondisi topografi wilayah Kabupaten Belu yang pada dasarnya merupakan wilayah perbukitan dengan kemiringan lahan berkisar antara 0 hingga lebih dari $45 \%$. Selain itu, jenis tanah dan kepekaannya terhadap erosi menjadi hambatan tersendiri terhadap lahan itu sendiri. 


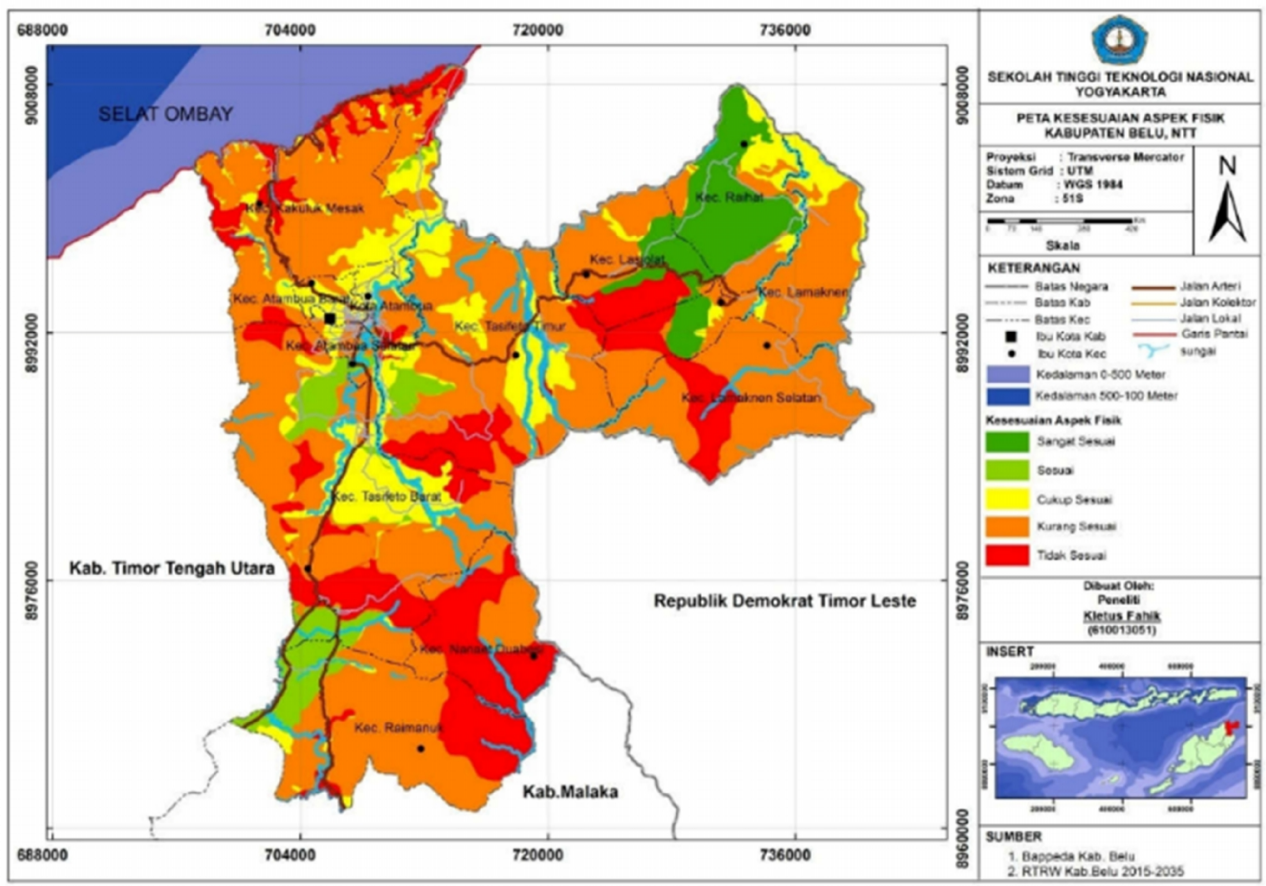

Gambar 4. Peta Analisis Kesesuaian Aspek Fisik Sumber: Analisis, 2018

\section{Analisis Kesesuaian Aspek Prasarana}

Analisis terhadap jaringan prasarana lingkungan sangat penting untuk dilakukan, karena sangat menunjang keberadaan suatu permukiman di suatu lokasi. Parameter yang digunakan dalam analisis ini yakni jaringan air bersih dan jaringan listrik.

Berdasarkan hasil analisis kelas kesesuaian lahan aspek prasarana yang mendominasi di Kabupaten Belu adalah kelas tidak sesuai (N2) dengan total luas 64.600 Ha atau 57\% dari total luas wilayah Kabupaten Belu. Selanjutnya adalah kategori kurang sesuai (N1) dengan luas sebesar 23.436,86 Ha atau 21\% dari luas wilayah Kabupaten Belu. Sedangkan untuk tingkat klasifikasi sangat sesuai (S1) seluas 928,26 Ha atau sekitar 1\% dari luas wilayah Kabupaten Belu. Berikut Gambar 5 peta kesesuaian aspek prasarana: 


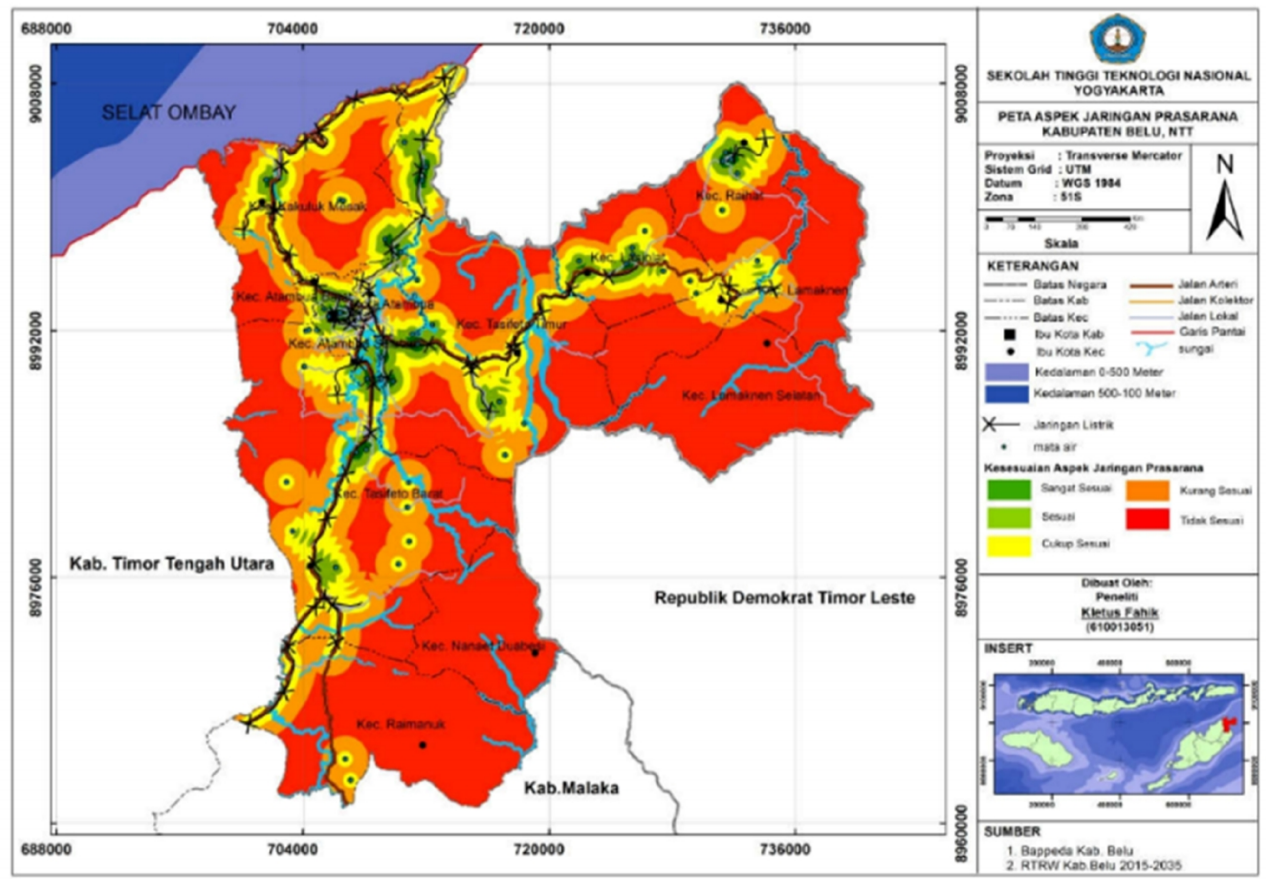

Gambar 5. Peta Analisis Kesesuaian Aspek Prasarana Lingkungan Sumber: Analisis, 2019

\section{Analisis Kesesuaian Aspek Aksesibilitas}

Analisis aspek aksesibilitas dalam penelitian ini dilakukan untuk melihat jarak lahan untuk lokasi permukiman terhadap ketersediaan jalan utama. Pada analisis ini, parameter yang digunakan adalah jaringan jalan utama dengan tidak mengklasifikasikan kedalam status jalan. Jika menggunakan teknik buffer, diperoleh tingkat kesesuaian lahan berdasarkan pembagian kelas jarak terhadap jalan utama.

Berdasarkan hasil analisis diperoleh tingkat kesesuaian lahannya terbagi menjadi lima bagian yakni kelas sangat sesuai dengan luas 24.771,91 Ha, kelas sesuai dengan luas 1.8261,06 Ha, kelas cukup sesuai dengan luas 14.880,75 Ha, kelas kurang sesuai dengan luas 12.105,19 Ha dan kelas tidak sesuai dengan luas 42.306,77 Ha. Berikut Gambar 6 peta kesesuaian aspek aksesibilitas: 


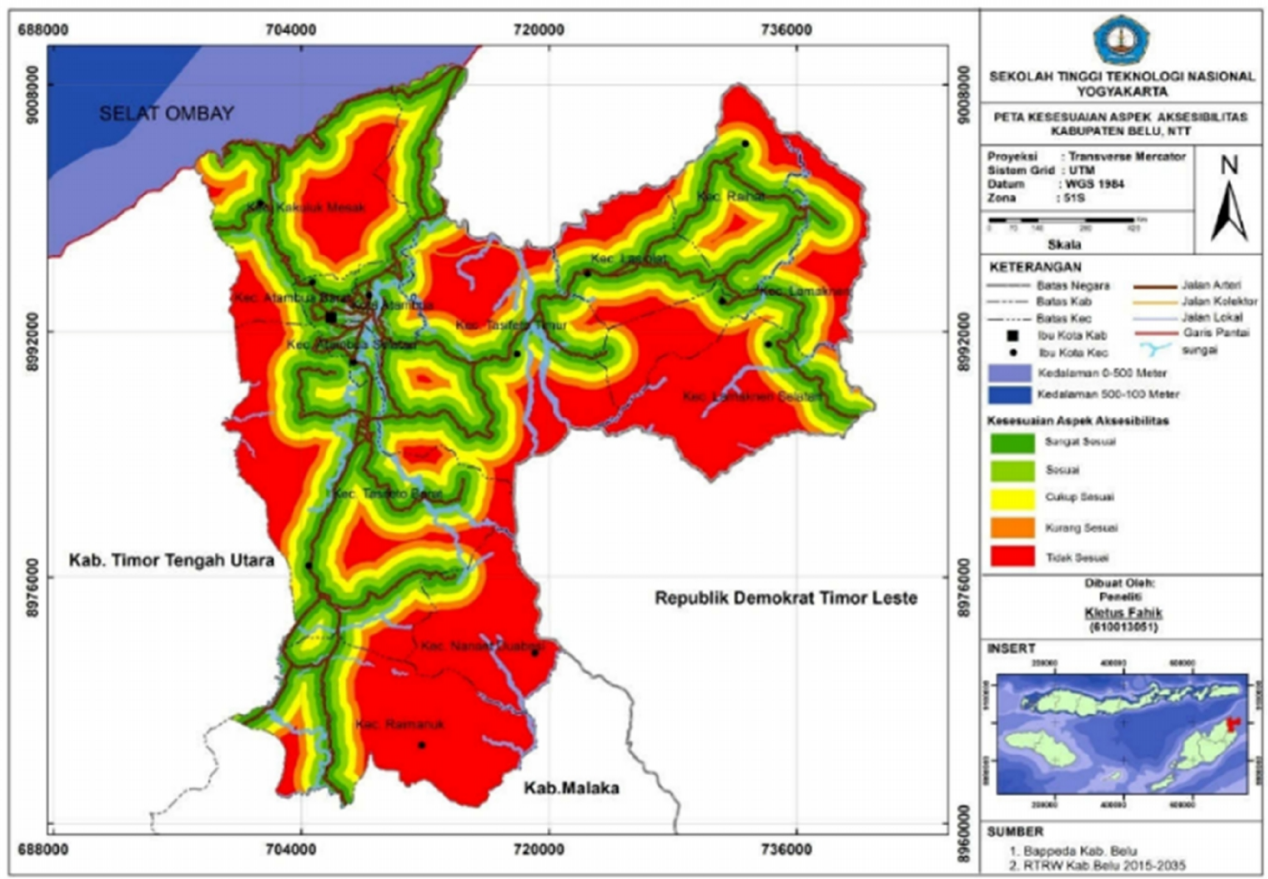

Gambar 6. Peta Analisis Kesesuaian Aspek Aksesibilitas Sumber: Analisis, 2019

\section{E. Analisis Aspek Kebencanaan}

Analisis terhadap aspek kebencanaan ini dilakukan dengan menggunakan analisis overlay atau tumpang susun parameter bencana banjir dan tanah longsor (Hardjowigeno, 2001). Dengan menggunakan pengscoringan dan pembobotan, analisis ini menghasilkan kesesuaian lahan untuk lokasi permukiman berdasarkan aspek kebencanaan.

Berdasarkan hasil analisis, tingkat kesesuaian aspek kebencanaan terbagi menjadi lima bagian yakni kelas sangat sesuai dengan luas 38.391,31 Ha, kelas sesuai dengan luas 60.870,98 Ha, kelas cukup sesuai dengan luas 12.719,96 Ha, kelas kurang sesuai dengan luas 320,17 Ha dan kelas tidak sesuai dengan luas 23,74 Ha. Berikut ini Gambar 7 peta kesesuaian aspek kebencanaan: 


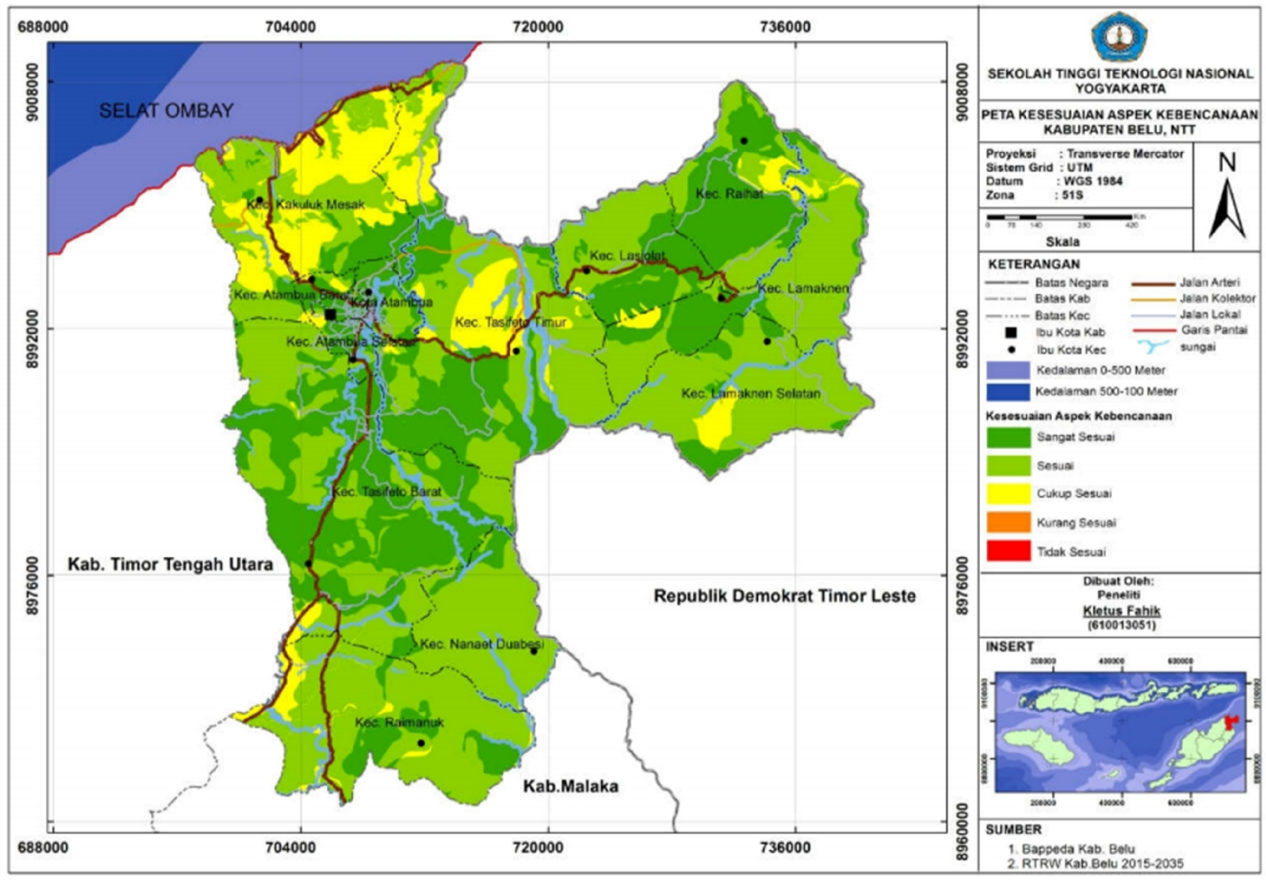

Gambar 7. Peta Analisis Aspek Kebencanaan Sumber: Analisis, 2019

\section{F. Overlay Analisis Kesesuaian Lahan Permukiman}

Analisis kesesuaian lahan permukiman berdasarkan seluruh aspek ini dilakukan untuk menemukan lahan yang sesuai untuk dijadikan sebagai lokasi permukiman di Kabupaten Belu. Langkah analisisnya adalah dengan melakukan scoring terhadap seluruh aspek. Scoring terhadap aspek-aspek ini mengacu pada skor total dari setiap parameter yang telah dioverlay. Selanjutnya dilakukan analisis overlay terhadap seluruh aspek kesesuaian lahan yang ditinjau. Setelah dioverlay seluruh aspek tersebut, dilanjutkan dengan perhitungan skor total keseluruhan aspek yang kemudian akan memperoleh nilai maksimum dan nilai minimum yang akan digunakan untuk menentukan lebar atau jarak interval kesesuaian lahan.

Berdasarkan hasil analisis diperoleh tingkat kesesuaian lahan berdasarkan seluruh aspek yakni kelas sangat sesuai dengan luas 3.811,50 Ha, kelas sesuai dengan luas 6.380,59 Ha, kelas cukup sesuai dengan luas 26.350,75 Ha, kelas kurang sesuai dengan luas 64.875,14 Ha, dan kelas tidak sesuai dengan luas 10.907,71 Ha. Berikut Gambar 8 peta kesesuaian lahan untuk permukiman sebagai berikut: 


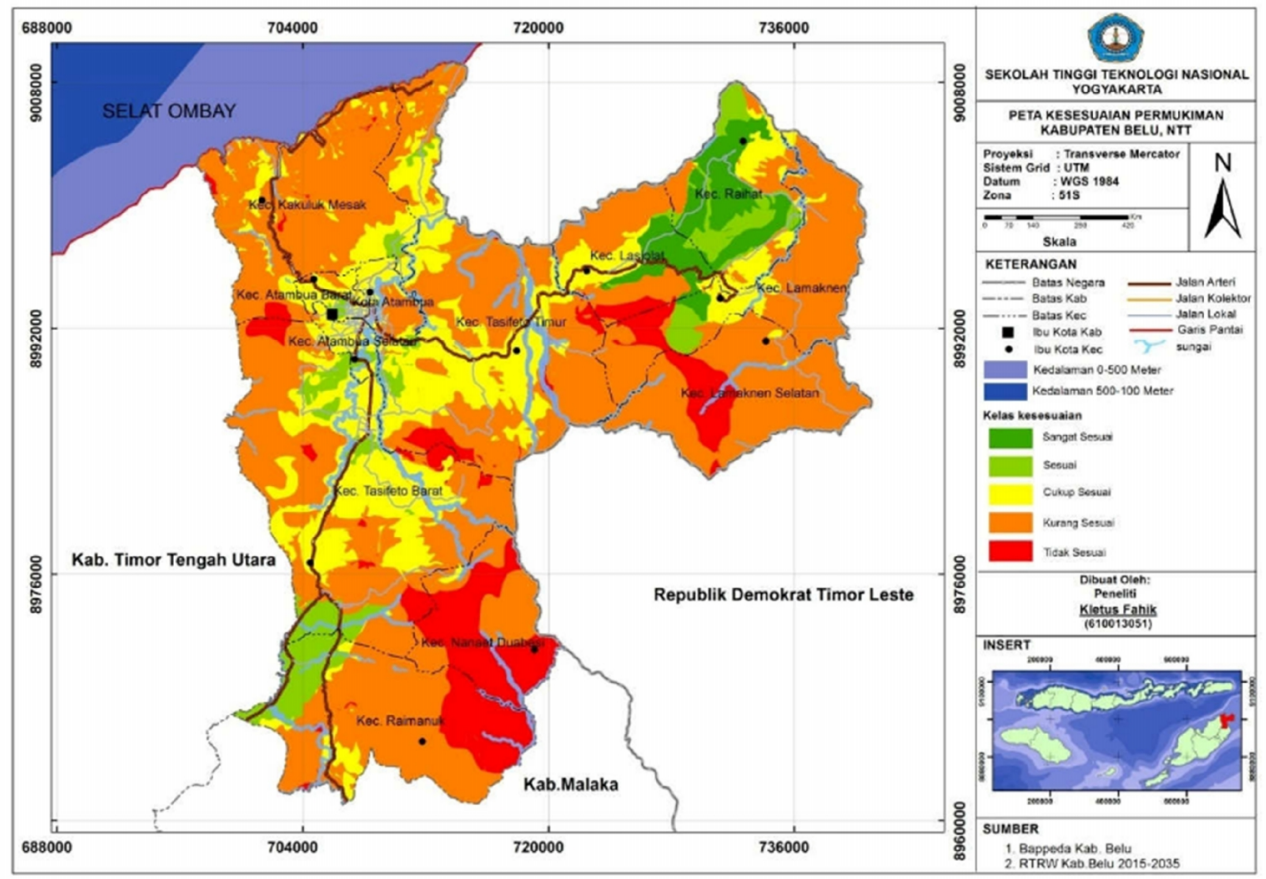

Gambar 8. Peta Analisis Kesesuaian Lahan Permukiman Sumber: Analisis, 2019

\section{G. Overlay Kesesuaian Lahan Terhadap Permukiman}

Analisis kesesuaian lahan untuk lokasi permukiman terhadap kawasan sempadan pantai dan sempadan sungai yang merupakan kawasan lindung. Analisis ini betujuan untuk mengetahui lokasi lahan untuk permukiman yang berada di luar kawasan sempadan sungai dan sempadan pantai. Analisis ini dilakukan dengan menggunakan teknik overlay dan juga buffer untuk menghitung jarak lahan dari sempadan yang dianggap sesuai.

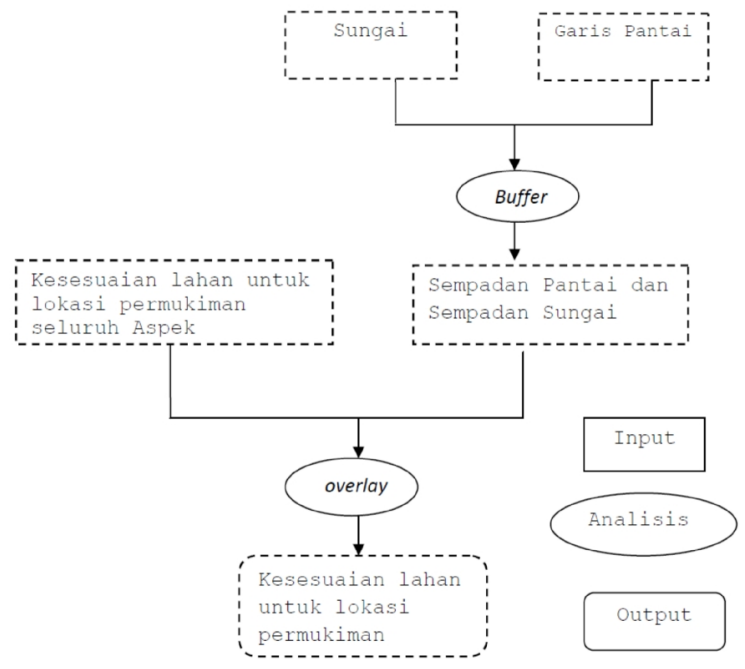

Gambar 9. Skema Analisis Kesesuaian Lahan Terhadap Sempadan Sumber: Analisis, 2019 
Parameter sempadan pantai dan sungai ini dengan analisis tool berupa buffering dengan ketentuan jarak sungai 50 meter dan buffer garis pantai sejauh 100 meter, sehingga menghasilkan peta sempadan sungai dan sempadan pantai. Selanjutnya peta sempadan sungai dan sempadan pantai dioverlay dengan peta kesesuaian lahan untuk lokasi permukiman berdasakan seluruh aspek.

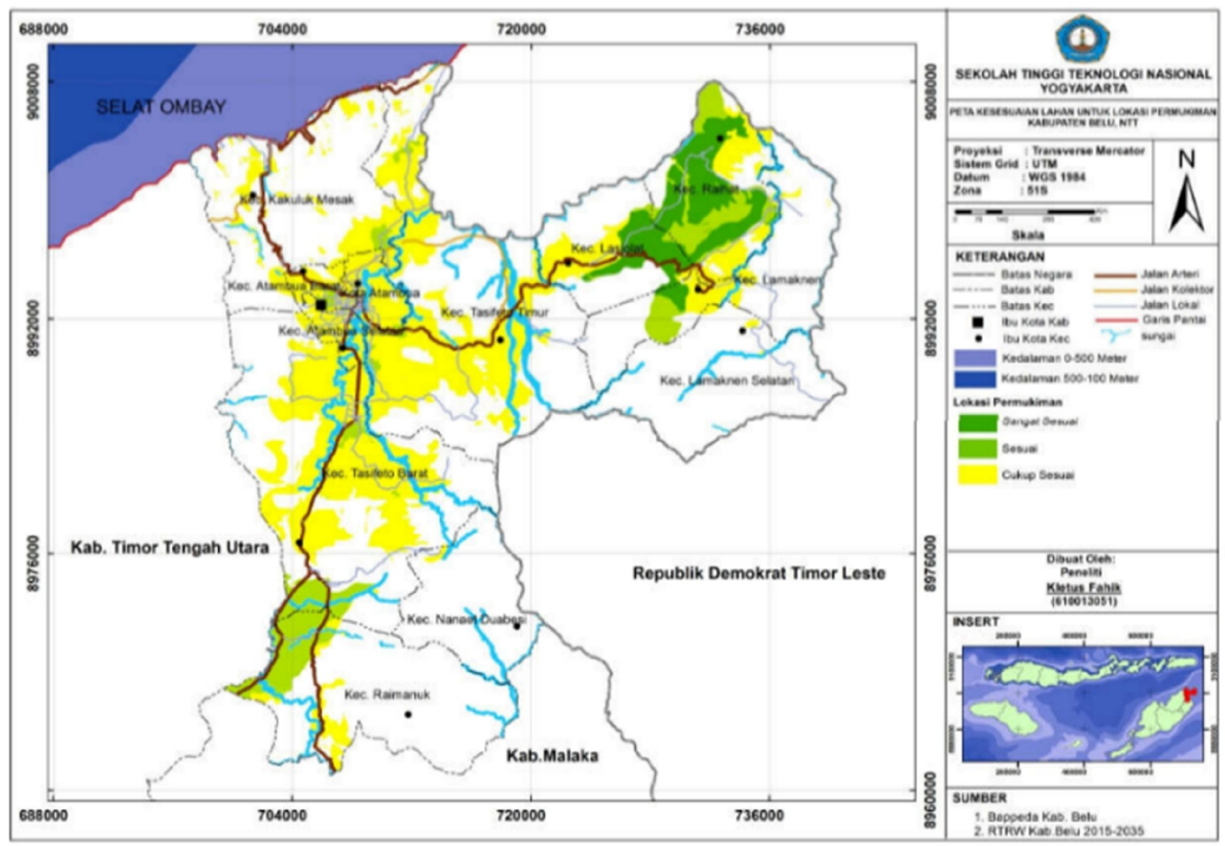

Gambar 10. Peta Analisis Kesesuaian Lahan Permukiman Sumber: Analisis, 2019

\section{H. Lahan Potensial Peruntukan Permukiman Kabupaten Belu}

Berdasarkan ketentuan dalam Tata cara pemilihan lokasi prioritas untuk pengembangan pembangunan perumahan dan permukiman di Kawasan Perkotaan (Balitbang,PU 2005) persyaratan umum lokasi permukiman diantaranya ketinggian lahan $<1000$ mdpl, serta kemiringann lereng tidak, melebihi 15\%. Namun dalam penelitian ini, kemiringan lereng 15-25\% dinyatakan sesuai namun bersyarat dijadikan lokasi untuk permukiman. Berdasarkan ketentuan tersebut, diperoleh lahan yang potensial untuk lokasi permukiman dalam penelitian ini yakni terbagi kedalam tiga kelas yakni Sangat Sesuai (S1), Sesuai (S2) dan Cukup Sesuai (S3). Berikut Gambar 11 peta lahan potensial untuk lokasi permukiman: 


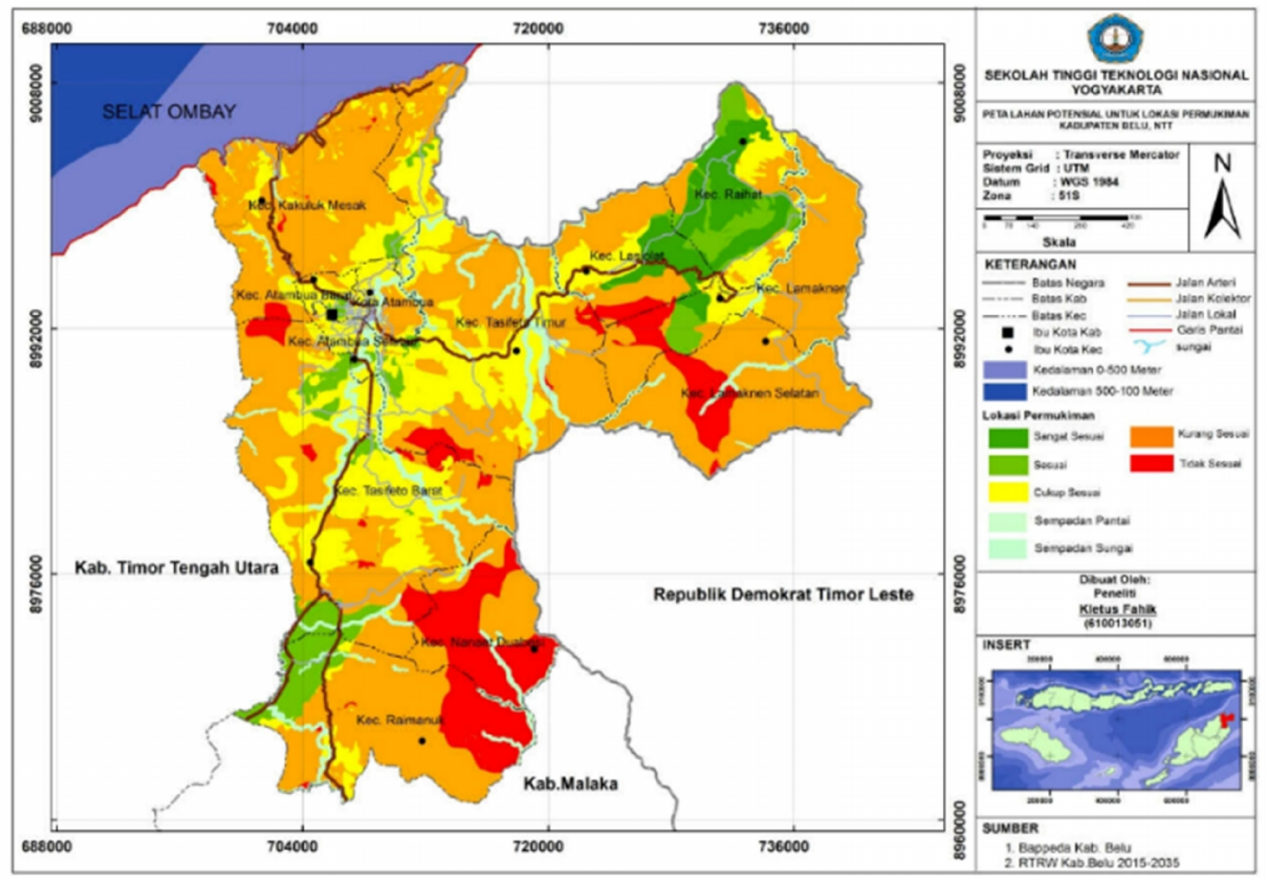

Gambar 11. Peta Lahan Potensial Peruntukan Permukiman Sumber: Analisis, 2019

\section{Analisis Kondisi Sosial Budaya}

Perkembangan suat wilayah atau kawasan sangat ditenukan oleh kondisi masyarakatnya, dimana hal ini dipengaruhi oleh kebiasan masyarakat dalam menjalankan sistem wilayah termasuk sosial dan ekonomi (Sakarov. 2018). Kabupaten Belu secara umum dihuni oleh tiga suku asli yakni suku Tetun sebagai suku terbesar, suku Kemak dan suku Marae. Selain itu terdapat juga suku-suku yang merupakan para pendatang yakni suku Alor, Sabu, Rote, Bugis, Tionghoa dan juga Jawa. Keberadaan suku-suku ini memberikan suatu penampakan kemajemukan wilayah dalam suatu wilayah. Keberadaan suku-suku ini tidak terlepas dari adanya pengaruh perkembangan jaman. Keberadaan para pendatangpun memicu adanya kemajemukan ini, dimana keberadaan mereka pada basis wilayah suku-suku dapat memberikan suatu situasi positif ataupun negatif. Kabupaten Belu berdasarkan hasil analisis lokasi potensial permukiman terbagi dalam 3 kelas yakni sangat sesuai, sesuai dan cukup sesuai. Dengan melihat keberadaan wilayah berdasarkan suku di Kabupaten Belu dapat diketahui sebaran suku-suku tersebut dengan keberadaan lahan potensial untuk permukiman yang dapat dilihat pada Gambar 11 tentang peta basis wilayah suku terhadap lahan potensial untuk lokasi permukiman. 


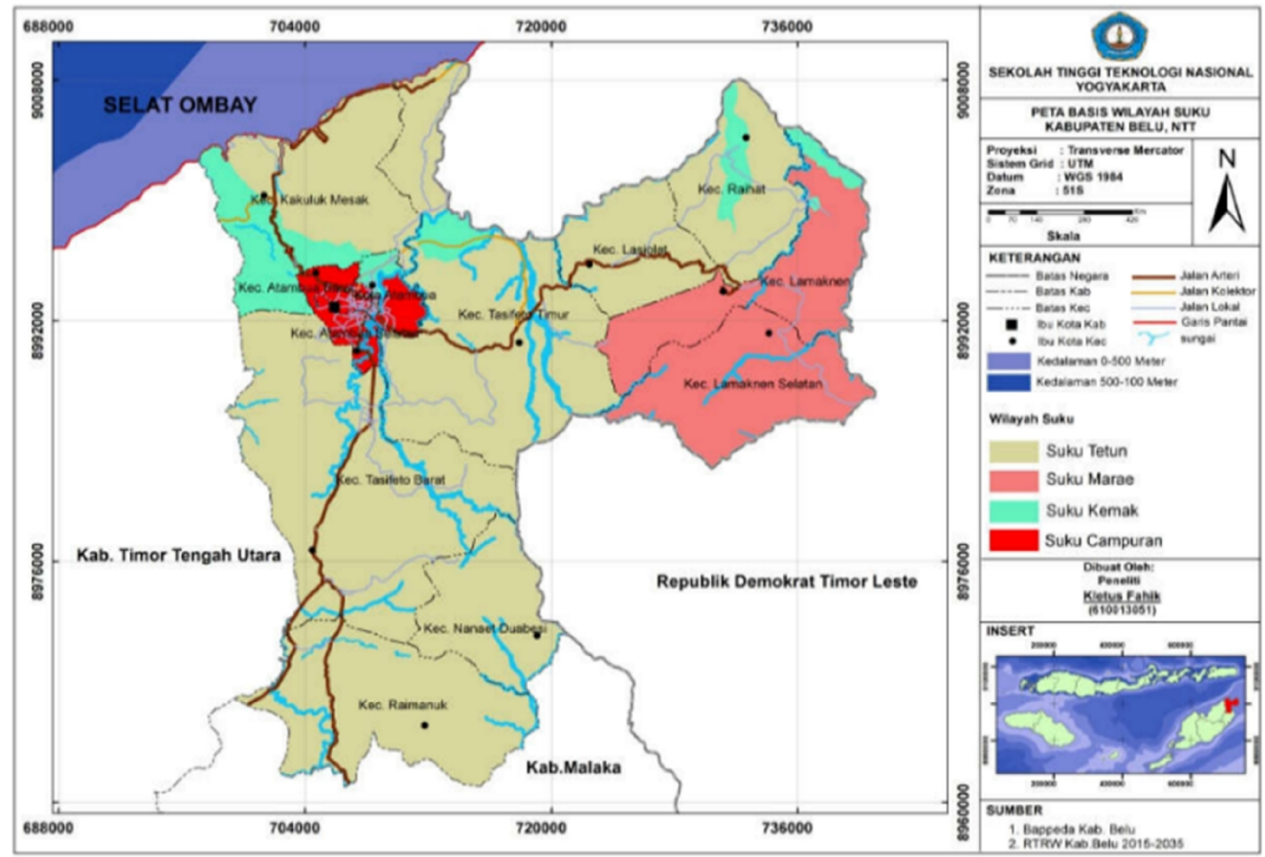

Gambar 12. Peta Persebaran Suku-Suku di Kabupaten Belu Sumber: Analisis, 2019

Secara umum masyarakat Kabupaten Belu sangat terbuka terhadap kehadiran para pendatang, dengan tetap mengacu pada adat istiadat yang berlaku dan tetap menjunjung tinggi nilai kebersamaan dan saling menolong tanpa membedakan suku, agama, dan ras.

Masyarakat Kabupaten Belu sangat menjunjung tinggi akan adat istiadat dan sikap toleransi serta gotong royong antar sesama. Berdasarkan data BPS 2017, mayoritas penduduk Kabupaten Belu beragama Kristen Katolik dengan prosentasenya 89\%, Protestan 7\%, Muslim 4\%, serta sisanya adalah Hindu dan Budha. Meskipun terdapat keberagaman dalam agama keharmonisan dalam bermukim bersama tetap terjaga.

\section{KESIMPULAN DAN SARAN}

\subsection{Kesimpulan}

Berdasarkan pembahasan pada bab sebelumnya, maka penulis dapat menarik beberapa kesimpulan, antara lain:

1. Terdapat beberapa kriteria pembagian kesesuaian penggunaan lahan di Kabupaten Belu yang layak untuk dijadikan sebagai lokasi permukiman yakni kelas sangat sesuai dengan luas 3.566,38 Ha, sesuai dengan luas 5.933,49 Ha dan sangat sesuai dengan luas 25.316,59 Ha. Kelas cukup sesuai (S3) sangat mendominasi pada lahan di Kabupaten Belu yang tersebar merata di seluruh wilayah Kabupaten Belu. 
2. Tidak semua lahan di Kabupaten Belu layak dijadikan sebagai lokasi permukiman. Hal ini ditunjukan dengan hasil analisis yang diperoleh kelas kesesuaian lahan yang mendominasi adalah kelas kurang sesuai (N2) dengan luas 64.875,14 Ha yang tersebar diseluuh wilayah Kabupaten Belu.

3. Kabupaten Belu terbagi menjadi 3 suku asli yakni suku Tetun, suku Marae dan suku Kemak serta beberapa suku pendatang yang berasal dari Alor, Rote, Sabu, Bugis, Tionghoa, dan Jawa. Identifikasi terhadap preferensi bermukim dalam keberagaman suku dan bahasa, Kabupaten Belu merupakan wilayah yang sangat nyaman bermukim dalam keberagaman suku ini, dan dalam hal keterterimaan terhadap suku pendatang masyarakat Kabupaten Belu sangat menjunjung tinggi nilai persaudaraan dan toleransi.

\subsection{Saran}

Pada penelitian ini penulis memberikan saran bagi pemerintah dan peneliti lain yang ingin membahas tema serupa, antara lain:

1. Hal yang cukup penting dalam proses penentuan lokasi permukiman adalah dengan mempertimbangkan aspek social dan budaya suatu wilayah, dimana perumahan yang dikembangkan sesuai dengan kondisi masyarakat setempat.

2. Perlu adanya penelitian lanjutan terkait dengan karakteristik lokal masyarakat Kabupaten Belu dalam menentukan hunian, sehingga pengembangan lokasi permukiman seiring dengan budaya dan kearifan lokal yang berkelanjutan.

\section{DAFTAR PUSTAKA}

Budiharjo, E.(1999). Lingkungan Binaan dan Tata Ruang Kota. Yogyakarta. Penerbit Andi.

BPS. (2015). "Belu dalam angka 2015", Pemerintah Kabupaten Belu, Belu. < http://belukab.bps.go.id (diakses 10 Desember 2017)

BPS. (2016). "Belu dalam angka 2016", Pemerintah Kabupaten Belu, Belu. $<$ http://belukab.bps.go.id (diakses 10 desember 2017)

BPS. (2017), Belu dalam angka 2017, Pemerintah Kabupaten Belu, Belu. < http://belukab.bps.go.id (diakses 10 desember 2017.

ESRI. 2010. “Arcgis 10.1 Help for Dekstop Advance”. <http://www.esri.com. (diakses 1 oktober 2017). 
Hardjowigeno, S.(2001). Evaluasi Kesesuaian Lahan dan Perencanaan Tataguna Lahan. Yogyakarta: Gadjah Mada Universty Press.

Keputusan Menteri Pertanian No. 837/KPT/UM/11/1980/1980. Jakarta: Pemerintah Republik Indonesia.।

Keputusan Presiden RI No. 32 Tahun 1990 Tentang Pengelolaan Kawasan Lindung. Jakarta. Badan Perencanaan Pembangunan Nasional (BAPPENAS)

Sakarov, O. D. (2018). Identifikasi Potensi Perkembangan Ekonomi Wilayah Kabupaten Sleman Dalam Konteks Urban-Rural Linkage. KURVATEK, 2(1), 73-84.

Pedoman Penyusunan RDTR dan Peraturan Zonasi Kabupaten/Kota No. 20 Tahun 2010.

Peraturan Daerah Kabupaten Belu Nomor 6 Tahun 2011 Tentang Rencana Tata Ruang Wilayah Kabupaten Belu Tahun 2011 - 2031

Peraturan Menteri PU nomor 20 tahun 2007 tentang Pedoman Teknik Analisis Aspek Fisik dan Lingkungan, Ekonomi serta Sosial Budaya dalam Penyusunan Rencana Tata Ruang.

Peraturan Menteri nomor 41 tahun 2007 tentang Pedoman Kriteria Teknis Kawasan Budidaya.

Prahasta, E. (2005). Sistem Informasi Geografis Konsep-Konsep Dasar. Bandung: Informatika.

Standar Nasional Indonesia 03-1733-2004 Tentang Tata Cara Perencanaan Perumahan di Perkotaan

Undang-Undang No. 1 tahun 2011 Tentang Perumahan Permukiman 